\title{
Bør vi spise mer mettet fett?
}

\author{
Ny forskning viser at mettet fett antakelig ikke er så usunt som man har trodd.
}

I flere tiår har det vært allment akseptert at mettet fett fører til økt forekomst av hjerteog karsykdom. Ny forskning setter imidlertid spørsmålstegn ved om dette er korrekt. En del nye studier peker nemlig i retning av at hovedårsaken til folkesykdommer som hjerte- og karsykdommer, overvekt og diabetes mellitus type 2 heller er å finne i et for stort inntak av raffinerte karbohydrater.

\section{Ny forskning}

Jeg hadde undervist sykepleiestudenter ved Høgskolen Stord/Haugesund om hjerte- og karsykdommer i tjue år, da jeg oppdaget en notis i Tidsskrift for Den norske legeforening som vakte min interesse. I nr. 10, 2010 skriver nemlig assisterende redaktør Erlend Hem følgende: «Mettet fett $\mathrm{i}$ kosten er ikke forbundet med økt forekomst av hjerte- og karsykdom. Det viser en metaanalyse i American Journal of Clinical Nutrition» (1, s. 130). Denne metaanalysen refererer til 21 ulike studier som til sammen inkluderte over 340000 mennesker i perioder på mellom 5 og 23 år, og konkluderer med at inntak av mettet fett ikke øker forekomsten verken av koronar hjertesykdom eller hjerneslag (2).

\section{Helseopplysning}

Høsten 2011 hadde jeg denne artikkelen i mente da jeg fikk en forespørsel fra ledelsen ved Høgsko-

\section{Hovedbudskap}

I flere tiår har man advart mot inntak av mettet fett, fordi man har trodd det kunne føre til økt forekomst av hjerte- og karsykdom. Ny forskning setter spørsmålstegn ved om dette er korrekt, og hevder at det sannsynligvis er et for stort inntak av raffinerte karbohydrater som er hovedårsaken til dominerende livsstilssykdommer som hjerte- og karsykdom, overvekt og diabetes mellitus type 2 .

\section{Søkeord}

Les mer og finn litteraturhenvisninger på våre nettsider. \Hjerteinfarkt \Hjerneslag \Kosthold len Stord/Haugesund om jeg kunne tenke meg å holde et foredrag over temaet: «Kost, helse og julefett». Det ble fortalt at dette var en nysatsning for å nå ut med viktig kunnskap til et større publikum, og at foredraget derfor skulle legges ut på YouTube (3). Jeg svarte ja på forespørselen, for jeg har alltid vært av den oppfatning at helseopplysning er en meget viktig oppgave for helsepersonell.

\section{Sunt fett}

Julefett (les mettet fett) var altså ett av stikkordene. Et av spørsmålene jeg måtte ta stilling til var om jeg skulle støtte de kostholdsanbefalinger som i flere tiår har gått ut på at man må unngå mettet fett $\mathrm{i}$ kosten fordi det gir økt forekomst av hjerteog karsykdom, eller om man skulle tillegge disse nye vitenskapelige funnene som ble trukket frem i artikkelen i Tidsskrift for Den norske legeforening større vekt. Etter å ha gjennomgått en stor mengde faglitteratur, kom jeg til at mettet fett i hovedsak synes å være sunt, og at inntaket kanskje til og med bør økes. Men jeg vil understreke at all kostholdsforskning er beheftet med en betydelig grad av usikkerhet. Det er så mange ulike variabler å ta hensyn til, og jeg forbeholder meg derfor retten til å endre standpunkt dersom pålitelig forskning senere skulle komme til en annen konklusjon.

\section{Karbohydrater}

Etter hvert som jeg leste meg ytterligere opp på temaet, ble jeg mer og mer overbevist om at den viktigste årsak til folkesykdommer som hjerte- og karsykdommer, overvekt og diabetes mellitus type 2 , er et for stort inntak av raffinerte karbohydrater, og spesielt karbohydrater med høy glykemisk indeks, og kanskje særlig monosakkaridet fruktose som blant annet finnes i sukker $(4,5,6,7,8,9)$. Raskt absorberbare karbohydrater gir høyt insulinnivå i blodet som synes å ha flere uheldige fysiologiske effekter. Det er for eksempel antydet at det gir en lavgradig kronisk betennelsestilstand i kroppen. Insulin er også et meget effektivt fettlagringshormon, og hyperinsulinemi synes å låse fettet til kroppen slik at vektnedgang blir vanskelig. Fruktose har riktig nok lav glykemisk indeks, men det kan kun metaboliseres i leveren og overbelaster derfor denne nokså fort, og er trolig derfor årsak til ikke-alkoholisk fettlever hos betydelige deler av befolkningen, og spiller også trolig en vesentlig rolle i utviklingen av metabolsk syndrom. Et høyt inntak av fruktose kan også føre til uheldige fysiologiske effekter som ugunstig fettsammensetning $\mathrm{i}$ blodet, høyt blodtrykk og annet. $(4,5,6,7)$.

\section{Overvekt}

Det er verdt å notere seg at mens fettandelen i kosten har gått betydelig ned fra 1980 og fram til i dag (fra 40 prosent til 30 prosent av energiinntaket), så har antallet overvektige, for eksempel i USA, økt kraftig i samme tidsrom, og nærmere 80 prosent av alle amerikanere regnes nå som overvektige (BMI over 25). Nylig kom det også tall som viser at 75 prosent av alle norske menn regnes som overvektige. Rundt år 1900 var 0,7 prosent av befolkningen i USA klassifisert som fete («obese»), det vil si en BMI på over 30. I dag gjelder dette 32 prosent av innbyggerne i USA (9). Mange forskere mener at dette i stor grad kan tilskrives en økning i inntaket av raffinerte karbohydrater, og kanskje særlig sukker og derved fruktose $(4,5,6,7,8,9)$.

\section{Hjerte- og karsykdom}

For 100 år siden var hjerte- og karsykdommer nesten et ukjent begrep i USA. I dag er det folkehelseproblem nummer én både i USA og Norge. I 1950 var det, for eksempel, 500 spesialister i kardiologi i USA, mens det i dag er 30000 (9). Mye tyder på at også økningen i forekomsten av hjerte- og karsykdom i stor grad kan skyldes et økende inntak av fruktose og karbohydrater med høy glykemisk indeks. $(4,5,6,7,8,9)$. Det gir nemlig en ugunstig lipidprofil. Det senker det gode kolesterolet, HDL. Det øker den farlige typen LDL (small dense LDL), og det øker triglyseridnivået (7).

\section{Fettinntak}

En del studier viser at inntak av mettet fett gjør det motsatte; det hever HDL-nivået, det senker triglyseridnivået, og det senker nivået av small dense LDL (7). Det er rapportert at 


\section{Hjerte- og karsykdom}

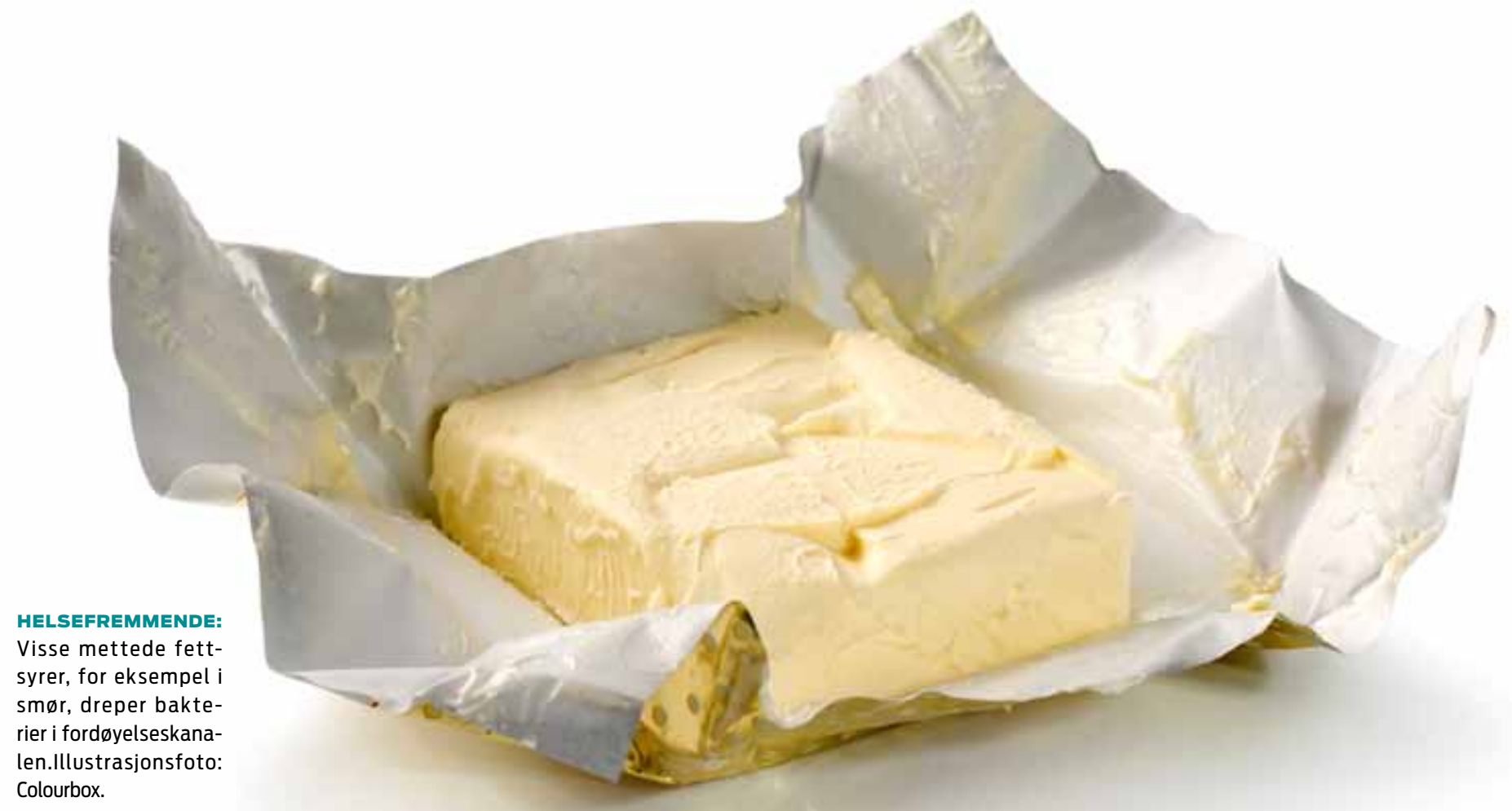

totalkolesterolverdien kan øke noe hos enkelte dersom man spiser mye mettet fett, men dette vil altså i all hovedsak skje ved en økning av HDL og det relativt ufarlige large buoyant LDL, og dette vil samlet sett $i$ alle fall ikke øke risikoen for hjerte- og karsykdom (7). Et annet og hud som blir eksponert for sollys konverterer kolesterol til vitamin D. Kolesterol er også en viktig del av cellemembranen. Det er til stede i særlig høy konsentrasjon i hjernen, spiller en vesentlig rolle i dannelsen av synapser, og kan således trolig spille en vesentlig rolle i viktige kognitive prosesser som

\section{«Det finnes også en del indisier på at ikke bare kolesterol, men også mettet fett er viktig for menneskekroppen.»}

vesentlig poeng,er at det er en del som tyder på at et høyt totalkolesterol i blodet i en del situasjoner ikke fører til økt total dødelighet, men kanskje snarere tvert om senker dødeligheten. Det finnes en del studier som viser at høyt totalkolesterol gir lavere total dødelighet hos for eksempel eldre mennesker og kvinner. Det er derfor grunn til å stille spørsmål ved om den omfattende bruk av statiner alltid er velbegrunnet $(10,12)$.

\section{Kolesterol}

En av grunnene til dette kan være at kolesterol er en meget viktig komponent i hver eneste celle i kroppen. Kolesterol er utgangspunktet for dannelsen av en rekke viktige hormoner som kortisol, testosteron og østrogen. Leveren konverterer kolesterol til gallesalter som er viktige for optimal absorpsjon av fett og fettløselige vitaminer som vitamin A, D, E og K, hukommelse og evnen til å lære (9). Kolesterol er også en del av kroppens vedlikeholdsapparat som reparerer celleskade, særlig de skadene som oppstår i arteriene ved åreforkalkning. En del forskere mener derfor at kolesterol i seg selv ikke er årsak til åreforkalkning, men heller er et ledsagende fenomen (12).

\section{Feil}

Overlege og professor i indremedisin ved Hälsouniversitetet/Linköping universitet, Fredrik Nyström, sier det slik: «Man har drevet og mast om fettfattig kost i 30 år, og så viser det seg å være helt feil. Det finnes ikke noen påvist sammenheng mellom mettet fett og hjerte- og karsykdommer» (11). Et av hovedpoengene er at et fettfattig kosthold automatisk betyr et karbohydratrikt kosthold, og omvendt. Grunnen til dette er at det kun er tre energigivende næringsstoffer av betydning; karbohydrat, protein og fett. Prosentandelen protein er relativt konstant på mellom 20 og 30 . Spiser man vesentlig mer protein enn dette risikerer man ubehagelige fysiske symptomer. Fastsetter man en fornuftig proteinmengde til 20 prosent, betyr det at 80 prosent av energiinntaket må dekkes fra enten fett eller karbohydrater.

\section{Harvard-studie}

I 2004 gjorde forskere ved et av verdens mest prestisjetunge universiteter, Harvard University, et overraskende funn da de skulle undersøke sammenhengen mellom kosthold og forekomsten av hjerte- og karsykdom. De studerte kvinner som hadde åreforkalkning i sine koronarkar, og sammenholdt kostholdsdata fra disse kvinnene med graden av forsnevring i koronarkarene. Artikkelen ble publisert i American Journal of Clinical Nutrition. Forskerne fant at det som i størst grad førte til forsnevring i koronarkarene var høyt inntak av karbohydrater. Det som gav noe mindre grad av forsnevring, var inntak av umettet fett, og det som kom best ut, som altså gav minst grad av forsnevring i koronarkarene, var inntak av mettet fett (13).

\section{Andre studier}

I 2005 kom det en rapport fra European Cardiovascular Disease Statistics som viste at jo høyere inntaket av mettet fett var i et land, jo lavere var forekomsten av hjerte- og karsykdom (9). En stor japansk studie viste at 


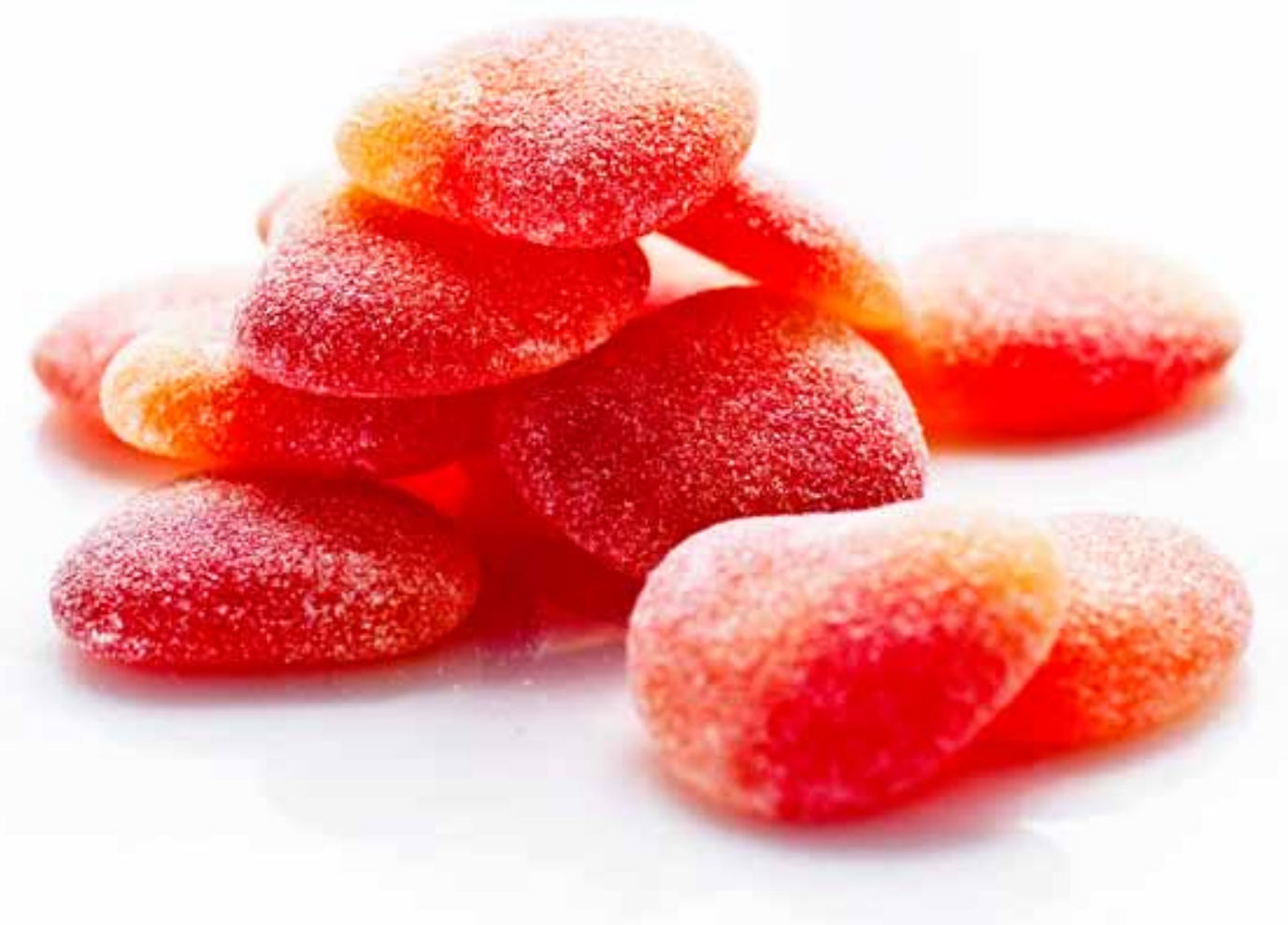

HOVEDFIENDEN: Nyere forskning viser at karbohydratene er verst med tanke på hjerte- og karsykdommer. Illustrasjonsfoto: Colourbox.

mettet fett beskyttet mot hjerneslag (14). En NTNU-studie viste at genene som disponerer for hjerte- og karsykdom, diabetes, kreft og demens i størst grad ble stimulert av et karbohydratrikt kosthold, og at fett stimulerte disse genene i mye mindre grad $(15,16)$. Og Cynthia Kenyon har vist at et karbohydratrikt kosthold fremskynder aldringsprosessen, noe som har resultert at hun selv har skåret betydelig ned på inntaket av raffinerte karbohydrater (17).

\section{Kvinnehelse}

For en tid tilbake kom også resultatene fra en av de dyreste og mest omfattende randomiserte intervensjonsstudiene noensinne, det såkalte «Womens Health Initiative». Studien ble publisert i det meget anerkjente tidsskriftet JAMA, og viste heller ingen reduksjon i forekomsten av hjerte- og karsykdom ved å redusere fettinntaket. Studien hadde følgende konklusjon: «The WHI Dietary Modification Trial is the largest long-term randomized trial of a dietary intervention ever conducted to our knowledge, and it achieved an 8,2\% reduction at year 6 in total fat intake and a mean daily increase of 1,1 servings of vegetables and fruits and 0,5 serving of grains. No significant effects on incidence of CHD or stroke were observed during 8,1 years of follow-up». Studien viste faktisk at de kvinner som hadde kjent hjerte- og karsykdom da studien begynte fikk en økning i forekomsten av hjerte- og karsykdom på 26 prosent ved å bytte ut deler av fettinntaket med inntak av karbohydrater (18).

\section{Mettet fett}

Det finnes også en del indisier på at ikke bare kolesterol, men også mettet fett er viktig for menneskekroppen. At det naturlige kroppsfettet vårt er mettet fett, og at 54 prosent av fettet i morsmelk er mettet fett kan være slike indisier. Cellemembranen trenger 50 prosent mettet fett for å oppnå optimal permeabilitet. Hjertet foretrekker de mettede fettsyrene palmitinsyre og stearinsyre som brennstoff (fremfor karbohydrater). Beinsubstansen trenger mettet fett for å kunne inkorporere kalsium på en effektiv måte. Lungenes surfaktant (som hjelper til med å holde lungeblærene åpne) og som kan hindre pusteproblemer består også av mettede fettsyrer. Mettet fett fungerer også som signalmolekyler ved hormonproduksjon, og i immunsystemet spiller mettet fett en vesentlig rolle. Det aktiverer hvite blodlegemer slik at de kan destruere invaderende bakterier, virus, sopp og kreftceller. Visse mettede fettsyrer som finnes i smør dreper bakterier og candida i fordøyelseskanalen. Dessuten er det viktig å være klar over at mettet fett gir stor grad av metthetsfølelse. Da spiser man mindre, og kan derved lettere opprettholde en normal kroppsvekt. Noe av det viktigste er kanskje at det å spise mye fett vil kunne hindre at man spiser større mengder raffinerte karbohydrater (9). IIII
LITTERATUR

1) Hem E. Mettet fett gir ikke økt hjerterisiko. Tidsskr nor legeforen 2010; 10: 130.

2) Siri-Tarino PW, Sun Q, Hu FB, Krauss RM. Meta-analysis of prospective cohort studies evaluating the association of saturated fats with cardiovascular disease. American Journal of Clinical Nutrition, 2010; 91: 535-46.

3) Halleraker JH. Kost helse og julefett. Foredrag ved Høgskolen Stord/Haugesund, 8/12-2011: <http://www.youtube.com/watch?v=T15JVJoTDMc> (Lesedato: 03.05.2012)

4) Norris J. Fructose is a poison says UCSF obesity expert. University of California San Fransisco. <http://www.ucsf.edu/news/2009/06/8187/ obesity-and-metabolic-syndrome-driven-fructose-sugar-diet> (Lesedato: 03.05.2012)

5) Lustig R. Sugar - the bitter truth. University of California Television. MiniMedicalSchool for the Public <http://www.youtube.com watch? $\mathrm{v}=\mathrm{dBnniua6}-\mathrm{oM}>$ (Lesedato: 03.05.2012)

6) Taubes G. The Diet Delusion. London: Vermilion, 2009

7) Taubes G. Why We Get Fat and What to Do About It. New York: Ancho Books, 2010.

8) Kuipers RS, de Graaf DJ, Luxvolda MF, Muskiet MHA, Dijk-Brouwer DJA, Muskiet FAJ. Saturated fat, carbohydrates and cardiovascular disease. The Netherlands Journal of Medicine. September 2011. Vol. 69. No. 9; 372-378.

9) Miller DW. Enjoy Saturated Fats - They're Good for You. University of Washington. School of Medicine. 17.juli 2011. <http://www.youtube.com/ watch?v=vRe9z32NZHY> [Lesedato: 03.05.2012]

10) Taubes $G$. The soft science of dietary fat. Sciencemag Vol 291. 30. Mars. No. 5513.2001 2536-2541 + 2543-2545.

11) Eenfeldt A. Matrevolusjonen. Oslo: Lille måne, 2011.

12) Ravnskov U. Fat and Cholesterol are Good for You.. Sverige: GB Publishing. 2009.

13) Mozaffarian D, Rimm EB, Herrington DM. Dietary fats, carbohydrate, and progression of coronary atherosclerosis in postmenopausal women. Am J Clin Nutr 2004; 80(5): 1175-1184

14) Yamagishi K, Iso H, Yatsuya H, Tanabe N, Date C, Kikuchi S, et al. Dietary intake of saturated fatty acids and mortality from cardiovascular diseas in Japanese: the Japan Collaborative Cohort Study for Evaluation of Cancer Risk (JACC) Study. American Journal of Clinical Nutrition 2010; 92(4): $759-765$.

15) Tunstad HJ. Genenes favoritt. Gemini (NTNU) 14. september 2011 <http:// www.ntnu.no/gemini/2011-03/9.htm> (Lesedato: 03.05.2012)

16) Brattbakk HR, Arbo I, Aagaard S, Lindseth I, de Soysa AK, Langaas $M$, Kulseng B, Lindberg F, Johansen B: Balanced Caloric Macronutrient Composition Downregulates Immunological Gene Expression in Human Blood cosilts-Adipose Tissue Diverges. OMICS. 16.6.2011.

17) Kenyon, Cynthia: <http://www.dailymail.co.uk/health/article-1323758/ Can-cutting-Carbohydrates-diet-make-live-longer.html> (Lesedato: 03.05.2012)

18) Howard BV, Van Horn L, Hsia J, et al. Low-fat dietary pattern and risk of cardiovascular disease: the Women's Health Initiative Randomized Controlled Dietary Modification Trial. JAMA. 8. februar 2006; 295 (6) 655-666 